\title{
Messages in Bottles: An Archive of Black Iraqi Identity in Diaa Jubaili's al-Bitrīq al-Aswad
}

\author{
Chip Rossetti
}

check for

updates

Citation: Rossetti, Chip. 2021.

Messages in Bottles: An Archive of Black Iraqi Identity in Diaa Jubaili's al-Bitrīq al-Aswad. Humanities 10: 82. https://doi.org/10.3390/h10020082

Received: 10 March 2021

Accepted: 26 May 2021

Published: 1 June 2021

Publisher's Note: MDPI stays neutral with regard to jurisdictional claims in published maps and institutional affiliations.

Copyright: (C) 2021 by the author. Licensee MDPI, Basel, Switzerland. This article is an open access article distributed under the terms and conditions of the Creative Commons Attribution (CC BY) license (https:// creativecommons.org/licenses/by/ $4.0 /)$.
Independent Researcher, Cranford, NJ 07016, USA; jjhrossetti@yahoo.com

\begin{abstract}
The novel al-Bițīq al-Aswad [The Black Penguin] by the Iraqi author Diaa Jubaili is a rare example of a contemporary Arabic novel that centers the experiences of Iraq's Black population, most of whom live near Basra in Iraq's south. The novel's mixed-race narrator recounts his life story in the form of letters addressed to international figures, highlighting the life of his family on the margins of Iraqi society and his later involvement with the real-life civil rights group, the Movement of Free Iraqis. This article draws on Stuart Hall's dual conception of cultural identity in diaspora to frame the characters' search for a Black Iraqi identity as a dynamic engagement with memory, one that represents a counternarrative in the face of legacies of African slavery and legal discrimination.
\end{abstract}

Keywords: Iraq; Blackness; fiction; refugee; racism

\section{Introduction}

The relative dearth of contemporary Arabic novels that center Blackness and antiBlack racism is a reflection of a greater silence about race-as well as the tangled historical legacy of slavery-within Arabic societies. While the connection between slavery and race in the Middle East was not as rigid and institutionalized as it became in the Americas, Blackness became linked to servitude and inferiority and remained so long after the Ottoman Empire and later states made slavery illegal. ${ }^{1}$ European colonialism in the Arab world-including, in Iraq's case, the period of British formal and informal colonial control, from the initial military occupation in World War I through the mandate period (1921-1932) to the overthrow of the monarchy in 1958-imposed European racializing practices and discourses, which continue to undergird the construction of race in the Middle East. ${ }^{2}$ As a result, as Eve Troutt Powell puts it, this linkage forms an "imagined map" in contemporary Arabic-speaking societies that buttresses and perpetuates a racial hierarchy. ${ }^{3}$ Compounding this anti-Black racism, as a number of scholars have pointed out, is the reality that in the Arab world, there is little public discourse about domestic racial issues. ${ }^{4}$ Stephanie Cronin characterizes this as a "generalized amnesia regarding Black slavery across the Middle East," which is responsible for "the social invisibility and marginalization of Black communities," and a lack of appreciation for the contributions of enslaved Africans to modern societies and culture in the region. ${ }^{5}$ More recently, Mona Kareem has pointed out a reluctance among Arab intellectuals to address the historical legacy of slavery when discussing anti-Black racism, "as if anti-Black racism has no history, trajectory, or realities beyond the stigma assigned to it, or the rhetoric surrounding it." 6

Some recent works of Arabic fiction have attempted to center issues of race in contemporary societies, whether in the systemic, structural discrimination experienced by

1 Ghenwa Hayek has stated that there is an "almost unanimous consensus in the scholarly literature" that Arab societies have traditionally associated Blackness with inferiority. Hayek (2017, p. 93).

2 Stoler (1995).

Powell $(2012$, p. 3).

Hayek (2017, p. 93).

Cronin (2016).

6 Kareem (2019) 
Blacks or their experiences of racial insults and daily microaggressions. ${ }^{7}$ As Kareem has written, these works of fiction can be problematic in their representations of race, and their choice of subject matter may reflect a cynical appeal to the interests of western academics, publishers, and NGOs. ${ }^{8}$ The novel al-Bitrīq al-Aswad [The Black Penguin] by the Iraqi author Diaa Jubaili (b. 1977), however, takes as its subject not only the historical legacy of slavery in Iraq's Basra region, but the real-life contemporary civil rights organization known as the Movement of Free Iraqis (Harakat al-'Irāqiyyin al-hurra), which was founded in 2007 to promote the rights of Black Iraqis and to call for an end to the racial discrimination they experience. $^{9}$

The novel's mixed-race male narrator relates his life story, including his adoption by a scholar and activist who belongs to the Movement of Free Iraqis. The narrator is both socially marginalized—Black, disabled, orphaned, and, later, a refugee-and a vessel for the expansive hopes of his adoptive parents. While drawing the reader's attention to a marginalized population of Black Iraqis in Basra, the novel is at pains to place their plight in a broader global context, even as it touches on links to African traditions in Afro-Iraqi music and dance, while finding connections to the American civil rights movement.

While exact numbers are difficult to come by, by one recent estimate, there are 400,000 Black Iraqis, most of whom live in the Basra province, particularly in the cities of al-Zubayr and Abu l-Khasīib. ${ }^{10}$ Modern Iraqis trace the presence of Blacks in the region to the Abbasid Empire, when large numbers of East Africans were enslaved to work on the reclamation of marsh lands. The harsh conditions of slavery led to the uprising known as the Zanj Rebellion during the years 255-270 Hijri [869-883 CE], which posed a serious threat to Abbasid authority and threatened to upend the social and political order in the region. ${ }^{11}$ While the Zanj Rebellion put an end to the widespread use of slavery for agriculture and land reclamation in southern Iraq, slavery continued as a legal practice, primarily for domestic, administrative, and military purposes, and was not exclusively linked to Blackness. ${ }^{12}$ Slavery continued to be legal in the Ottoman Empire (of which Iraq was a part). The need to replenish the population of slaves for elite households led to the development of large slave-trading networks that imported enslaved people from both the Caucasus and Africa in the nineteenth century. However, in the wake of the Tanzimat reforms, and under pressure from the British, the Ottoman state formally prohibited the African slave trade in 1857, and the institution itself declined, mostly disappearing by the early twentieth century, although it continued in some post-Ottoman Gulf states until after World War II. ${ }^{13}$ It is likely that this more recent slave trade, rather than the distant Zanj Rebellion, explains the sizeable Black presence in the Basra region today. Al-Bitrīq al-Aswad is not the first Iraqi novel to feature this population: recent examples include Murtadā Gzār's 2009 novel Maknasat al-janna and Jubaili's own 2009 novel Būghīz al-'Ajīb. Mahdī 'Īsā al-Saqr's 2005 novel al-Maqāma al-Bașriyya al-'Așriyya even features the leader of the Zanj, 'Alī ibn Muhammad, as a character brought back to life in contemporary Basra. ${ }^{14}$

Modern Iraq has had a complex relationship with Blackness, at times acknowledging Black populations and individuals as integral elements of Iraqi history and culture and also embracing Blackness in a gesture of solidarity with other colonized peoples of the global South. British colonial rule in the mandate period underscored connections between beauty and whiteness. ${ }^{15}$ At the same time, however, Iraqi intellectuals often expressed revulsion at

\footnotetext{
7 The English term "microaggression" is generally rendered in Arabic as al-ittidā' al-ṣaghìr. However, it does not seem to be in wide use in Arabic and often appears in news articles in the context of racism in the United States. See, for example, Jabalī (2020).

Kareem (2019).

Jubaili (2021).

The Killing of George Floyd Sparks Controversy over African-Iraqi Rights (2020).

Kennedy (2004, pp. 177-79).

Kennedy $(2004$, p. 177)

Toledano (1998, pp. 3, 10) and Erdem (1996, p. 58).

Gzār (2009), Jubaili (2011) and al-Ṣaqr (2005).

5 Although little has been published specifically on the imposition of European racial categories in Iraq during the mandate period, see López (2005).
} 
European racial theories, linking them to the injustice of the British occupation of their own country. In his 1939 study, al-Muqaddima fí-l-Ijtimā' [Introduction to Sociology], for example, the Iraqi intellectual 'Abd al-Fattāh Ibrāhīm rejected notions of racial purity-both Western claims to white supremacy and the focus on "pure Arab" bloodlines by contemporary Iraqi Pan-Arabists-as unscientific fictions. ${ }^{16}$ Similarly, Iraqis have long admired individuals identified as Black from the pre-Islamic or early Iheslamic period, whether literary figures such as the semilegendary warrior-poet 'Antara ibn Shaddād, who was born into slavery to an African mother, or the Abbasid-era writer al-Jāhiz. In the mid-twentieth century, left-leaning Iraqi intellectuals, such as Fayșal al-Sāmir and the novelist Dhū l-Nun Ayyūb, championed the Zanj Rebellion as an early example of a revolutionary social movement of Iraq's oppressed populations against unjust authorities. ${ }^{17}$

The 20-year-old narrator of al-Bitrinq al-Aswad relates his life story in the form of seven letters addressed variously to U.S. President Barack Obama, directors of different UN organizations, and American actress Angelina Jolie. He writes them in 2015 from western Turkey, having fled Iraq, in the hope of finding a boat that will smuggle him to Europe in the same way as millions of other refugees. He has written these letters to place them in bottles in the unlikely possibility that they will eventually reach their recipients as a way of drawing attention to his situation in particular, and to Black Iraqis more broadly. As he writes in his letter addressed to UN representatives, he does not hold out much hope for his own survival once he manages to find a boat ("It is probable that I will drown in the Aegean accompanied by dozens of fleeing refugees"), making these letters a desperate, nearly futile attempt at communication. ${ }^{18}$ Messages in bottles are a common cultural and literary motif, most often associated with white, European explorers stranded on islands, such as the fictional Robinson Crusoe, a colonizer and slave owner from the European "age of exploration." Jubaili's novel reverses and subverts this common motif: here, it is not the colonizer but the colonized sending messages out into the greater world.

The unnamed narrator recounts his life story nonchronologically, but the details become clear across the seven letters: he was born in Basra in 1995 during the sanctions era to a white father and Black mother. ${ }^{19}$ While identifying as Black throughout the book, the narrator also acknowledges his mixed-race background by referring to himself as muwallad. ${ }^{20}$ As a result of the deprivations of the sanctions years, three of his brothers died of malnourishment in infancy, while he himself was born with weak leg bones that made him bowlegged and kept him from walking until he was five. His only surviving sibling is his older sister Najma. ${ }^{21}$ His father divorced his mother and abandoned the family entirely following the birth of the narrator, whom he rejected as being both Black and disabled ("He considered me merely handicapped, and above all, Black.").22 As he can only crawl, the neighborhood children call him "the black worm" and "the seal." He only begins walking at age five, when his bowlegged gait gives him the nickname "the black penguin." ${ }^{3}$ The taunting nicknames make explicit the linkages between Blackness and disability in the minds of his neighbors, as bodies marked by social stigma that justifies their social exclusion and othering. ${ }^{24}$ Being both Black and disabled, the narrator is intersectionally disadvantaged; his double marginalization in the novel underscores the social construction

\footnotetext{
Bashkin (2009, p. 132) and Ibrāhīm (1939).

Bashkin (2009, pp. 218-19) and Davis (2005, p. 135). See also al-al-Sāmir (1954) and Ayyūb (1962).

Jubaili (2021, p. 62).
}

19 The narrator describes his Iraqi father throughout as simply "white." The novel's usage of the terms "Black" and "white" align with Western racializing categories, and the history of racialization in the contemporary Arab world is closely tied to the history of European colonialism. See Da'na (2004).

20 In some instances, the narrator also uses the term mū $\bar{u} \bar{t} \bar{u}$, a transliteration of the now dated and offensive Spanish word "mulatto," although his adoptive father Dr. Khamīs later explains to him the origins of the word and advises him not to use it. Jubaili (2021, p. 28).

24 Boehmer (1993, p. 268). On a more theoretical level, Alice Hall lays out the overlap between disability studies and postcolonial theory on her study of disability in literature. See Hall (2018, pp. 47-52). 
of racial difference as a form of disability and of disability itself as "always ... racialized, gendered, and classed." 25

Blamed by her brother for her divorce, his mother ends up taking a job working as a groundskeeper for a school. She also suffers from breast cancer, likely a result of her earlier work collecting radioactive scrap metal around Basra. ${ }^{26}$ The violence that descends upon Iraq in the wake of the 2003 invasion and occupation, followed by civil war in the years afterward, is mirrored by the violence inflicted on the family by the narrator's father, who returns and insists on marrying Najma off at age 12. It is the first time the young narrator lays eyes on his father, and he is shocked to find that he is not Black, although he then understands the reason for his sister Najma's lighter skin color. ${ }^{27}$

The following year, his mother disappears: the narrator never learns why, although she may have been killed by her brother, at the instigation of her former husband. His father then takes him at age 10 to live with him and his new family. Pulling him out of school, his father eventually—with the encouragement of his new wife-turns him over to a "beggars' shelter," an organization that runs a dormitory for beggars and profits off them. He is made to become a professional beggar and his father receives a monthly payment for "renting out" his son.

As a professional beggar, his disability is no longer a source of shame that he feels he must conceal but is instead something he is obliged to display. On his first day, the shelter's director scolds him for not emphasizing his lameness, telling him, "You have to show this crookedness in your legs, this ugly lameness, so people can see you as you walk like a penguin. Like this!" ${ }^{28}$ His humiliating enforced performance of disability in public reminds him of his earlier performance in a propaganda film made by the Ba'ath regime three months prior to the 2003 invasion. In the narrator's telling, the film gathered young disabled Iraqis in a studio to present them as victims of the birth defects caused by international sanctions and radioactive material from the 1991 war. He is only saved from life on the streets when Dr. Khamīs al-Aghā and his wife Shawqiyya "buy him out" from his father and informally adopt him so they can re-enroll him in school.

Dr. Khamīs al-Aghā, a lecturer at the University of Basra, is a saint-like mentor for the narrator and a role model of an educated Black Iraqi. In the novel, the fictional Dr. Khamīs introduces the narrator to the Movement of Free Iraqis civil rights group, as well as its real-life founder, Jalāl Dhiyāb. In 2009, as was widely reported in the international media at the time, the Movement celebrated the election of Barack Obama as a positive example for Black Iraqis. The narrator recalls that celebration in the novel when he visits the group's headquarters and is introduced to Dhiyāb. ${ }^{29}$ In reality, Dhiyāb's civil rights demands-and the awakening of a new sense of identity among Black Iraqis - posed a threat to Islamic political parties, which also took exception to his group's open admiration of American political figures such as Martin Luther King, Jr., and Barack Obama. As a result, Dhiyāb was assassinated on a street in Basra in 2013. ${ }^{30}$ Reflecting on Dhiyab's death, the narrator notes that it "passed in silence without any fuss worth mentioning." 31

After his assassination, Dhiyāb became known as "the Basran Martin Luther King," but in the novel, the narrator makes clear the extent of the gap between the American civil rights leader and his Iraqi counterpart. In his letter addressed to Obama, the narrator asks him:

"Jalāl Dhiyāb—have you heard of him? Of course, how would you have heard about him? He is not famous, and that is one of the differences between your

25 James and $\mathrm{Wu}(2006$, p. 8). For an earlier study on the historical uses of the concept of disability to justify racial discrimination in the US and the routine assumptions linking non-white races with disability and infirmity, see Baynton (2001, p. 36).

Jubaili (2021, p. 156)

Jubaili (2021, p. 179)

Bārāk Ubāmā aṣbaḥa namūdhajan lil-Irāqiyīn al-sūd (2009).

The Killing of George Floyd Sparks Controversy over African-Iraqi Rights (2020).

Jubaili (2021, p. 24). 
version and ours. Your Martin Luther King ... changed America's thinking and subjugated its leaders, caused Blacks to rise up, and drew the world's attention to their suffering at the hands of white Yankee ignorance. As for our version, unfortunately, local residents hardly know who Jalāl Dhiyāb is, and many of them mock his courage and his ambitions and his demand that the existence of the Black Iraqi constituency be acknowledged and included in the constitution." 32

He then goes on to list for the reader the specific set of demands that Dhiyāb and his group made, including an official apology for a long history of discrimination and greater educational opportunities. The frustrating silence surrounding Dhiyāb's murder-as well as the narrator's frustrated search for his mentor, Dr. Khamīs, who goes missing on the same day as Dhiyāb's killing — reflects a public sphere that cannot accommodate Dhiyāb's assertion of Black identity. The narrator relates as an example a public event on minorities in Iraq in which Dhiyāb participated and at which an Iraqi politician in attendance declared that Black Iraqis were "the salt of society" - an affectionate but condescending phrase that the narrator sardonically repeats over the course of the novel-while insisting that an organization dedicated to the rights of Blacks would "tear apart the fabric of Iraqi society." 33 The politician's statement comes to stand for a broader tendency to ignore or erase the unique historical experiences of Black Iraqis in the name of social harmony. As Edward Said has noted, this "power to give or withhold attention is a power utterly essential to interpretation and politics," and thus the text deliberately compels its readers-both the international figures to whom the narrator addresses his letters and the readers of the novel itself-to pay attention to these facts about Black Iraqi lives.

While the narrator points out incidents of contemporary stereotyping that Black Iraqis confront, he is also keen to draw connections to the past and to the way Iraq's present racial hierarchy reinscribes older, silenced histories. Slavery in Iraq is not a phenomenon from the distant past, he notes, but existed as recently as 60 years ago. He compares Black street sweepers in modern Basra to the al-shurjiyya, a term for slaves from centuries ago who were tasked with sweeping or raking up salt from the topsoil of the marshes near Basra, "while their backs are beaten by the cruel whips of feudal landowners, as well as by the rays of Basra's merciless sun." ${ }^{\prime 34}$ In contrast to the ahistorical fixation on skin color and visual representations that Mona Kareem has decried in contemporary discussions on anti-Black racism in the Arab world, The Black Penguin is keen to point out that stereotypes about Blacks in contemporary societies have long cultural antecedents. ${ }^{35}$ The novel quotes an old Arabic saying about the zanj and their stereotypical predisposition for "natural rhythm" ("If a zanj fell down to earth from heaven, he would only fall in rhythm!"). ${ }^{36}$ Elsewhere, the narrator reminds his readers of more recent examples of legal discrimination faced by Black Iraqis: that until 1924, Iraqi civil records used "slave" ('abd) instead of "Black" to indicate an individual's race, and that the government kept Blacks out of government schools until as late as $1960 .^{37}$

For the narrator, the most direct and painful reminder of the past's hold on the present is the ongoing use of that same insulting term 'abd ("slave") to designate Black Iraqis, while reserving hurr ("free") as a synonym for "white." This elision of Blackness with slavery is not unique to Iraq but is recognized as a racial insult elsewhere in the Arabic world: Ghenwa Hayek, for example, characterizes 'abd as an "enduringly common racial epithet" in Egypt and the Levant. ${ }^{38}$ As the narrator explains to Obama, the fact that Black Iraqis themselves use the terms ' $a b d$ and hurr suggests that they have internalized this racial

Jubaili (2021, p. 23).

Jubaili (2021, p. 139)

Jubaili (2021, p. 18). As a footnote to this page explains, the al-shurjiyya were among the first to join the Zanj Rebellion in the 9th century.

Kareem (2019).

Jubaili (2021, p. 53).

Jubaili (2021, p. 121).

38 Hayek (2017, p. 93). See also Powell (2012, p. 3), on the potency of the word among Egyptian journalists and the pain it evokes in Sudanese refugees in Cairo. 
binary. In Gramscian terms, this racial hierarchy operates hegemonically over the class of Iraqis most disadvantaged by it. This internalization of the term 'abd plays out in the narrator's own family, as his grandmother argues that it is a good thing that the narrator's sister Najma has the opportunity to marry a "free" man-in fact a relative of her white father. ${ }^{39}$

Other myths about Blacks provoke the narrator's anger, including dehumanizing myths about Blacks and sex. He objects to an Iraqi urban legend, for example, that says that sleeping with a Black woman can cure a backache (a legend that a neighborhood tormentor teases him with by suggesting that he slept with the narrator's sister). Likewise, stereotypes about Black men's sexual prowess and appetite are pernicious and have deep cultural roots: as he explains to Obama, they appear not only in contemporary pornography but in the writings of prominent premodern authors such as Galen, al-Qazwīnī, al-Mas' ${ }^{\mathbf{u}} \mathrm{d} \overline{\mathrm{i}}$, and Shamsuddīn al-Dimashqī. ${ }^{40}$

While The Black Penguin is primarily focused on confronting its readers with details about the historical legacy of slavery in Iraq, the narrator also saves his anger for the United States, particularly in his letters addressed to Obama. He takes the U.S. president and his country to task for being ignorant of history in general, and of the history and culture of Iraq in particular. (Taking umbrage at Obama's presumed ignorance of the Iraqi poet Badr Shākir al-Sayyāb, he asks him, "You do not know him either? If you have not heard of him, then I hope you take a good look at your culture, sir.") $)^{41}$ He draws links between American war atrocities in Iraq and its own history of racism and genocide, reminding Obama that the U.S. was built "on the corpses of Indians and African slaves," and comparing the destruction on the "Highway of Death" at the end of the 1991 Gulf War to "the limbs of Indians scattered on both sides of the Trail of Tears." 42 Connecting the status of Blacks in Iraq with the history of American racism and imperialism suggests an authorial decision to link the two in the mind of his Iraqi readers, even though his narrator takes pain to distinguish the experiences of Black Iraqis from the racial terror, legal discrimination, and harassment experienced by American Blacks. ${ }^{43}$ Thus, while the letters addressed to Obama initially suggest that the narrator (and perhaps by extension, the author) holds an uncritical admiration for a Black political figure, these later critical comments demonstrate that the narrator is well aware that Obama is implicated in America's complicated legacies of racism and of atrocities committed in Iraq. ${ }^{44}$

In the face of these painful historical legacies, the novel posits the almost saintly character of the narrator's adoptive father, Dr. Khamīs al-Aghā, who we learn has made it his personal mission to be an archivist and student of Black Iraqi identity and culture. His efforts, as recollected by the narrator, encompass both concepts of cultural identityas something reclaimed from the past and as something dynamically produced in the present-described by sociologist Stuart Hall in his influential essay, "Cultural Identity and Diaspora." Hall laid out the first concept of cultural identity as one of a unified, shared culture, "a sort of collective, 'one true self'," representing a past that can be reclaimed or rediscovered through a form of anticolonial cultural archaeology. ${ }^{45}$ Like the Black artists of the Caribbean and Americas who are the focus of Hall's article, Dr. Khamīs cultivates an interest in African origins as a source of cultural identity. Dr. Khamīs, for example, listens to old songs played on the drum known as the khashshäba as an aural connection to African

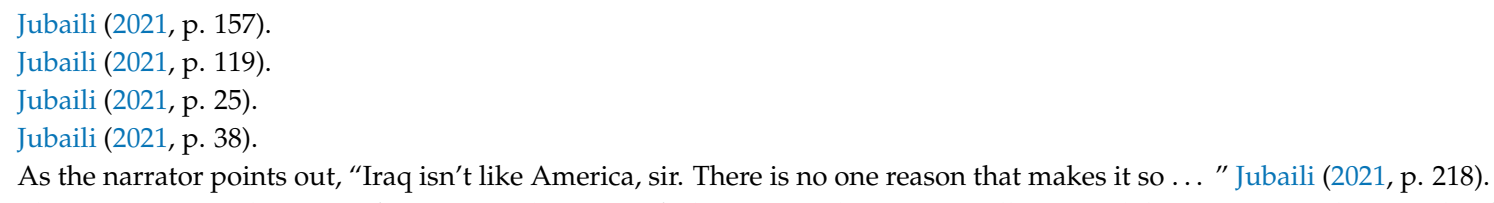

4 The narrator's combination of positive and negative feelings towards America calls to mind the poem "Amrīkā, Amrīkā" ["America, America"] by the Iraqi poet Saadi Youssef (born near Basra in Abū l-Khașīb), which evokes America's dual nature, as a nation that evokes images of freedom but that also practices violence, as rendered in Khaled Mattawa's English translation: "I love Mark Twain and the Mississippi steam-/boats and Abraham Lincoln's dogs./I love the fields of wheat and corn and the smell/of Virginia tobacco./But I am not American./Is that enough for the Phantom pilot to turn me/back to the Stone Age?" Youssef (2003).

45 Hall (1990, p. 223). 
traditions. He finds the singers' voices "blend the pain of longing, and blend musical and vocal connections derived from folkloric Swahili technique ... for the inherited African legacy it represents." ${ }^{46}$ Dr. Khamīs not only teaches himself East African languages but studies songs that were originally religious in origin which "the ancestors had brought

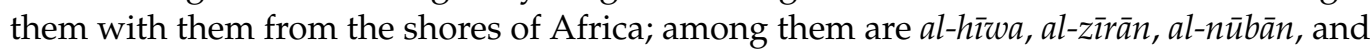
al-jakānkā." Dr. Khamīs traces obscure song lyrics that were originally Swahili and were distorted in spoken Arabic. ${ }^{47} \mathrm{He}$ also delves into the African origins of the dance known as al-lìwa, popular throughout the Gulf, as a reflection of the sufferings experienced by enslaved Africans. The narrator finds them similar to American musical genres such as jazz and hip-hop, "which came about as an expression of what Blacks in America were suffering," the difference being that, as he puts it, Black Iraqis do not have the cultural visibility of Black Americans, nor a distinctive enclave like Harlem that has come to stand for their group identity. ${ }^{48}$

However, Dr. Khamīs's quest to embrace and champion a Black cultural identity is not limited to recovering distant connections to Africa. Crucially, he is also interested in engaging what it means specifically to be a Black Iraqi. In that sense, he adheres to Stuart Hall's second conception of cultural identity, as something produced and dynamic, rather than static and recoverable. In this view, identity is not grounded "in the archeology, but in the re-telling of the past," that is, an ongoing engagement with memory. ${ }^{49}$ Dr. Khamis compiles a growing personal archive about Black Iraqis, including thousands of documents and fading photos, all of which the narrator inherits on Dr. Khamīs's disappearance.

Dr. Khamīs's archive represents a counternarrative to official histories, an attempt to document and preserve personal and collective histories that otherwise would be lost. The fragility of these memories is demonstrated early in the book, at the first mention of the informal archive, when the narrator learns from Dr. Khamīs the story of a Black Iraqi named Malik, a former amateur boxer. In the months before the 1991 Gulf War, Malik abandoned his military unit and went up to Baghdad to try to meet the American boxer Muhammad Ali, who had come to Iraq to arrange the release of Americans being held by the Iraqi government. ${ }^{50}$ No one is certain whether Malik succeeded in meeting him, because he suffered permanent brain damage and memory loss from a bomb fragment after the war began, and lost the autograph he once claimed to have received from Muhammad Ali. The uncertainty about Malik's encounter with Muhammad Ali echoes both a broader amnesia about Blacks in Iraqi history and society, and the severing of Black Iraqis from a solid sense of cultural and historical identity. Dr. Khamīs's archive becomes the repository for memories and a bulwark against forgetting, a role at which it succeeds, since, as the narrator explains, it includes a photograph of Muhammad Ali visiting a shrine in Baghdad, with Malik standing in the background, and thus preserves the only piece of evidence that Malik met his boxing hero. ${ }^{51}$ Dr. Khamīs's efforts to build an archive as a means of asserting identity and countering a broader neglect by authorities parallels in miniature the problems confronted more broadly by scholars studying the archives of formerly colonized societies. Omnia Shakry characterizes this problem as one of "history without documents" (a term borrowed from the Egyptian historian Ibrāhīm 'Abduh), which she takes to mean "the history that we might seek to reconstruct because of, and despite, the absence of access to such documents." ${ }^{152}$ Black Iraqis have little representation in official historical records, having been neglected by British imperial authorities and by more recent Iraqi authorities. However, archives, as Shakry points out, are more than simply official material records: they are also an "instituting imaginary," which allows a reassembling of the past, one that

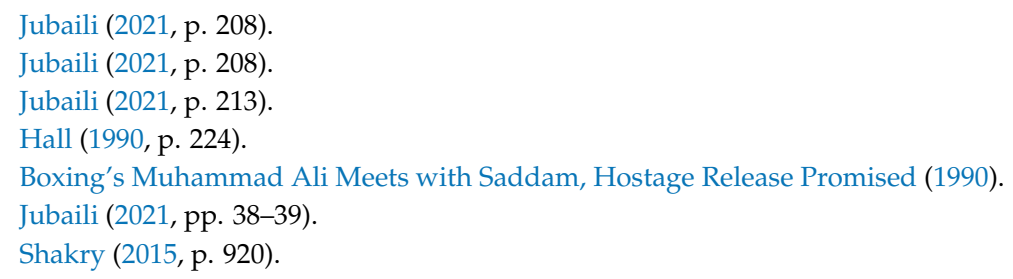


is inevitably incomplete, but also "at least partially, the projection of our own desires." 53 The archive in this instance represents an alternative possibility, a fictional recuperation of silenced and forgotten histories. ${ }^{54}$

Jubaili's novel presents a vision of Iraqi history that foregrounds the presence of Blacks as an integral element in Iraq's past. The narrator himself is reminded of this presence as the object of a long litany of racially tinged insults and nicknames, often linking him to Black figures from pre-Islamic history: at various times, he is mockingly called "Abraha al-Habashī" (after the Ethiopian general who led a pre-Islamic invasion of the Arabian Peninsula), "Bilāl" (after a Black companion of the Prophet Muhammad), "al-Najāsh̄̄" (after the Arabic term for the ruler of Axumite Ethiopia), and "Antara ibn Shaddād" (after the Black pre-Islamic poet, born into slavery). ${ }^{55}$ At a reenactment of the Battle of Karbala, the adolescent narrator plays the role of Jawn bin Huway, the only Black among Husayn's supporters, only to find that his racist neighbor, an antagonist named Rā'id ibn Suhayl al-Haddād, is playing an opponent and takes advantage of his role to beat and kick the narrator with enthusiasm. ${ }^{56}$

If Blackness is a cause for taunting and insult at the hands of the narrator's teachers and neighbors, it is also a fact that the narrator's mentors—Dr. Khamīs and Jalāl Dhiyāb—wish to reinscribe into Iraqi history. He also hears from Dr. Khamīs about "the Black caliph," Abū Iṣhāq Ibrāhīm ibn al-Mahdī, the half-brother of the Abbasid caliph Hārūn al-Rashīd, who briefly claimed the caliphate against the claims of his nephew al-Ma'mūn. According to Dr. Khamīs, Ibrāhīm ibn al-Mahdī was the son of an enslaved Black woman. ${ }^{57}$ The narrator himself muses on the theory that the Biblical character of Nimrod (2200-2154 BC) had black skin, suggesting the presence of Africans in Iraq in its earliest historical period. ${ }^{58}$

Dr. Khamīs's own family history, as described in the novel, reveals the historical connection between slavery and castration, as well as a surprising source of wealth that once belonged to a small class of Blacks in Basra. Dr. Khamīs' family name, "al-Aghā," derives from a number of wealthy Blacks known as the "aghass of Mecca," who were eunuchs that had served in Mecca and chose to emigrate to Basra upon retirement. Their wealth came from gifts bestowed by pilgrims and was gradually lost over generations. ${ }^{59}$ Some aghās-like Dr. Khamīs' forebear, the narrator learns-married Black women and adopted their children. ${ }^{60}$ However, as the narrator reminds the reader, Dr. Khamīs's family history is an exception, as most Blacks in Basra, having lost the origins and names that linked them to their African ancestors, instead carry the names of the families that once owned them, such as al-Sa'dūn, al-Naqīì, al-Ka'bī, al-Hāshimī, al-Bū Muḥammad, al-Qaysī, and al-Tamīmī. In many cases, enslaved Africans were given the names of plants, animals, or stones, such as Turquoise (fìrūz), Sandalwood (sandal), or Camphor (kāfür). To rename something —or someone-is to assert a right of possession over it, and thus Black Iraqis' names reflect a permanent rupture of identity. ${ }^{61}$ In the narrator's words, their names have become "a legacy of slavery that we can never get rid of." 62

For the narrator, the racial insults he experiences on a daily basis can seem like a sexual assault, and his inability to fight back against them evokes for him the castration of slaves, a practice that was widespread during the Ottoman Empire, which followed the practice of earlier states. As a university student on his way home, he is mocked by the nine-year-old brother of his bullying antagonist, Rā'id, who chants the rhyming insult in

\footnotetext{
Shakry (2015, p. 920).
}

54 Shetty and Bellamy (2000, p. 25). Greg Forter, in his recent study of utopias and postcolonial fiction, has written that postcolonial historical fiction exists at the "dialectical conjugation of recover's impossibility with its necessity." Forter (2019, p. 1). 
colloquial Arabic, 'abd 'abd țangūra, qūm imsih al-sabūra (meaning, "excited Black slave, go wipe down the writing board."). The narrator is certain Rā'id taught his younger brother that expression, but he realizes he cannot take his anger out on the child:

"I struggled to keep my nerve, and with difficulty I kept it in check, the way someone does with an agitated bull. I tamped it down forcefully, until I imagined that I heard a sound like the scream of slaves from the 13th century as they were being castrated and had their manhoods taken from them." 63

The evocation of castration looms large in the narrator's mind as a metaphor for the frustrations and humiliations he experiences.

The idea of castration occurs as well in the narrator's relations with his father. A flashback late in the novel explains that Dr. Khamīs brought the narrator back to his father and offered to pay him more than he was getting from hiring his son out as a beggar, so that he could complete his education. In order to do this, he has to persuade his father to relinquish his son's official documents so that he can be re-enrolled in school. The father's first reaction is to project onto Dr. Khamīs a desire for control symbolized by the historical practice of castration, perhaps a subconscious acknowledgment of Dr. Khamīs's superior position, as a Black man who is both wealthier and more educated than him. In response to Dr. Khamīs's offer, the narrator's father replies, "Additionally, if I refuse?... Will you castrate me?" At times in the past, the narrator's father had also threatened him with castration and described him as a eunuch, but the narrator also seems to attribute his father's deliberate evocation of this practice to an unthinking absorption of racialized cliches, rather than a conscious awareness of brutal historical practices: "If it were not for his ignorance of history, and of the presence of this savage practice in the history of Black slavery, then I would think he believed he was saying it to Dr. Khamīs with the intent of insulting him ..." ${ }^{\prime 64}$

The sexual violence of castration as a form of racial dominance hovers just below the surface in these scenes, but other legacies also color the narrator's relationships in the novel. In particular, the phenomenon of internalized anti-Black racism-and its assumptions and preferences about sexual desirability and availability_intrude in an online romantic relationship he begins with a young Black woman, a theater student named Nūrā. The section on Nūrā is the most lighthearted in the novel, but even there, racism-and the narrator's self-conscious awareness of its legacy and impact-interferes. He had initially contacted her when he found her phone number on a piece of paper while attending a public demonstration. Their relationship proceeds exclusively online and over the phone, which leads to layers of confusion and deception over race and identity, on both sides: Nūrā, for example, poses as a white woman online, and when she asks him to send her an explicit photo of himself, he hesitates, fearing that she is indulging in racial stereotypes. He later learns, to his surprise, that she believed he was white also. When they agree to meet in person outside her house, she never turns up, as she refuses to believe that the Black man she sees loitering outside is the same person she has been talking with online and later tells him she thought he was "an 'abd trash collector." 65

His anger at her about her use of the term 'abd changes when he later learns that she is, in fact, only pretending to be white herself, by passing herself off as a white friend whose family employs her as a maid while she attends university. When the narrator confronts her, and she tearfully admits to the deception. He upbraids her for succumbing to self-hating cultural myths about desirability and skin color, but his anger is tempered by the realization that she suffers from what Frantz Fanon called an "epidermalization of ... inferiority" imposed by society. ${ }^{66}$ As he tells her, "In any case, it's an inferiority complex, a complex deeply embedded in the human soul in a form that elicits regret and sympathy 
for people of humanity." ${ }^{\prime 67}$ In return, however, she accuses him of operating under the same inferiority complex, since he believed he was pursuing a white woman. The legacy of racism poisons the narrator's attempt at a romantic connection, which becomes another in a series of losses and disappointments that drive him eventually to flee Iraq for Europe.

Most devastating for the narrator is the disappearance of Dr. Khamis, who goes missing on the same day in 2013 that his colleague Jalāl Dhiyāb is murdered. The narrator is just beginning medical school, and with the support of Dr. Khamīs's wife, he begins a months-long, fruitless search for Dr. Khamīs among Basra's criminal underworld, where kidnapping groups offer him the tantalizing possibility that his adopted father and mentor is still alive. Dr. Khamīs's money - the last of the wealth of the aghās of Mecca-is drained by the payment of bribes that never lead anywhere. His final bribe goes to arranging a meeting with a corrupt police commissioner, who turns out to be the former director of the shelter where he was once rented out as a beggar-a bitter commentary on the type of person who rises to power in an environment of official corruption and greed.

The former director turns out to be a powerful criminal who claims to know what became of Dr. Khamīs. However, with no further money for bribes, the medical student narrator is given the option of paying in kind by performing amputations on kidnap victims. Shawqiyya's death by stroke soon afterward makes him "an orphan for the second time." 68 Unwilling to do the gruesome work the criminal mastermind holds over his head, and with no further family or adopted family to keep him in Basra, he makes the decision to drop out of sight and leave Iraq for good.

While the narrator's litany of misfortunes offers a bleak assessment of the present, his story implies a possibility of hope for the future, as it suggests that his sister Najma is still alive and has a young son who suffers from the same walking problem as his uncle. It is the past, however, that offers a rich sense of community and identity, despite painful legacies. Returning from Shawqiyya's memorial service to an empty house, the narrator finds that it has been robbed. He finds Dr. Khamīs's archive tossed on the floor, and appreciates for the first time its power to evoke a Black Iraqi past that is both a repository of pain and a source of creativity:

"I picked it up, and at that moment I felt its weight for the first time, as though I were carrying a history of pain and suffering and torments. Even when I opened it up to look through it, I imagined I could hear the sounds of screaming, the rattle of chains around cracked feet, and whips falling on bare backs. I heard Black fishermen on the shores of al-Faw peninsula as they strike the wood of their boats and invent a hybrid Swahili art form. They combine words from their mother tongue with words from common spoken Arabic, to form singing styles that still resonate in the throats of singers who practice the art of khashshāba down to our day." ${ }^{\prime \prime}$

As a product of his efforts to assemble and preserve elements of Black Iraqi life and history that might otherwise be forgotten, Dr. Khamīs's archive embodies Stuart Hall's concept of the past as "always constructed through memory, fantasy, narrative and myth" rather than as fixed in essence and origin. ${ }^{70}$ The archive, patiently pieced together over the years, represents a powerful repository of identity, but it is fragile, the novel suggests. Ultimately, the archive is lost, as the ransacked house is sold, and the narrator does not take it with him as a refugee. The narrator's own story represents a smaller-scale version of the archive: like the archive, the narrator's account forms a narrative of Black Iraqi life and-relayed in the form of messages that will be sealed in bottles and tossed into the Mediterranean with little hope of reaching their destined recipients-is similarly vulnerable to being lost forever.

Funding: This research received no external funding.

7 Jubaili (2021, p. 255).

68 Jubaili (2021, pp. 301-2).

69 Jubaili (2021, pp. 302-3).

70 Hall (1990, p. 226). 
Institutional Review Board Statement: Not applicable.

Informed Consent Statement: Not applicable.

Conflicts of Interest: The author declares no conflict of interest.

\section{References}

al-Sāmir, Fayṣal. 1954. Thawrat al-zanj. Baghdad: Dār al-Qāri'.

al-Ṣaqr, Mahd̄̄ 'Īsā. 2005. Al-Maqāma al-Bașriyya al-'Așriyya. Baghdad: Dār al-Shu'ūn al-thaqāfiyya.

Ayyūb, Dhūl-Nun. 1962. Li-l-Haqīqa wa-l-Tārīkh: Jumhūriyyat 14 Tammūz wa Mufajjir thawratihi wa Ibn al-Sha'b al-Barr 'Abd al-Karīm Qūsim. Baghdad: al-Sharika al-Wațaniyya li-l-Ṭibā'a wa-l-I'lān.

Bārāk Ubāmā aṣbaḥa namūdhajan lil-Irāqiyīn al-sūd. 2009. CNN Arabic. February 19. Available online: http://archive.arabic.cnn.com/ 2009/entertainment/1/20/iraq.blacks/ (accessed on 28 May 2021).

Bashkin, Orit. 2009. The Other Iraq: Pluralism and Culture in Hashemite Iraq. Stanford: Stanford University Press.

Baynton, Douglas. 2001. Disability and the Justification of Inequality in American History. In The New Disability History: American Perspectives. Edited by Paul K. Longmore and Lauri Umansky. New York: New York University Press, pp. 33-57.

Bearman, P., Th. Bianquis, C. E. Bosworth, E. van Donzel, and W. P. Heinrichs, eds. 2012. Encyclopaedia of Islam, 2nd ed. Leiden: Brill Online.

Bodenhorn, Barbara, and Gabriele vom Bruck. 2006. Entangled in Histories': An Introduction to the Anthropology of Names and Naming. In The Anthropology of Names and Naming. Edited by Gabriele vom Bruck and Barbara Bodenhorn. Cambridge: Cambridge University Press, pp. 1-30.

Boehmer, Elleke. 1993. Transfiguring: Colonial Body into Postcolonial Narrative. Novel: A Forum on Fiction 26: 268-77. [CrossRef]

Boxing's Muhammad Ali Meets with Saddam, Hostage Release Promised. 1990. Associated Press, November 27. Available online: https:/ / apnews.com/article/ae7d3a67b1cb4abd5e100821ce810805 (accessed on 28 May 2021).

Cronin, Stephanie. 2016. Islam, Slave Agency and Abolitionism in Iran, the Middle East and North Africa. Middle Eastern Studies 52: 953-77. [CrossRef]

Da'na, Seif. 2004. History and Race Consciousness in the Arab World: Colonial Capitalism and the Construction of Race. In Race and Identity in the Nile Valley: Ancient and Modern Perspectives. Edited by Carolyn Fluehr-Lobban and Kharyssa Rhodes. Trenton: Red Sea Press, pp. 241-64.

Davis, Eric. 2005. Memories of State: Politics, History, and Collective Identity in Modern Iraq. Berkeley and Los Angeles: University of California Press.

Erdem, Y. Hakan. 1996. Slavery in the Ottoman Empire and its Demise, 1800-1909. Basingstoke and London: Macmillan Press Ltd.

Fanon, Frantz. 1967. Black Skin, White Masks. Translated by Charles Lam Markmann. New York: Grove Press.

Forter, Greg. 2019. Critique and Utopia in Postcolonial Historical Fiction: Atlantic and Other Worlds. Oxford: Oxford University Press.

Gzār, Murtạ̣ā. 2009. Maknasat al-jannah. Baghdad: Dār Azmina lil-nashr wa-l-tawzī’ .

Hall, Alice. 2018. Literature and Disability. New York: Routledge.

Hall, Stuart. 1990. Cultural Identity and Diaspora. In Identity: Community, Culture, Difference. Edited by Jonathan Rutherford. London: Lawrence \& Wishart, pp. 222-37.

Hathaway, Jane. 2009. Eunuch Households in Istanbul, Medina, and Cairo During the Ottoman Era. Turcica 41: 291-303. [CrossRef]

Hayek, Ghenwa. 2017. Whitewashing Arabic for Global Consumption: Translating Race in The Story of Zahra. Middle Eastern Literatures 20: 91-104. [CrossRef]

Ibrāhīm, 'Abd al-Fattāh. 1939. al-Muqaddima fī-l-Ijtimā'. Baghdad: Maṭba'at al-Ahālī.

Jabalī, Malīka. 2020. Mu'aẓạm al-muṣābīn min al-sūd. Fīrūs kūrūnā yu'arrī haquīqat al-naẓām al-ṭabaqī al-'irqī fī l-wilāyāt al-muttahịa. 'Arabī Būst. May 28. Available online: http:/ / bit.ly/3aWDO4n (accessed on 28 May 2021).

James, Jennifer C., and Cynthia Wu. 2006. Editors' Introduction: Race, Ethnicity, Disability, and Literature: Intersectionality and Interventions. MELUS 31: 3-13. [CrossRef]

Jubaili, Diaa. 2011. Būghīz al-'Ajīb. Manama: Mu'assasat al-Dawsarī lil-thaqāfa wa-l-nashr.

Jubaili, Diaa. 2021. Al-Bițrīq al-Aswad. Beirut: Manshūrāt al-Hijān.

Kareem, Mona. 2019. Arabic Literature and the African Other. Africa Is A Country. Available online: https://africasacountry.com/2019 /05/how-do-arabs-talk-and-write-about-black-people (accessed on 28 May 2021).

Kennedy, Hugh. 2004. The Prophet and the Age of the Caliphates, 2nd ed. Harlow: Pearson.

López, Alfred J. 2005. Postcolonial Whiteness: A Critical Reader on Race and Empire. Albany: State University of New York Press.

Powell, Eve Troutt. 2012. Tell This in My Memory: Stories of Enslavement from Egypt, Sudan, and the Ottoman Empire. Stanford: Stanford University Press.

Shakry, Omnia. 2015. "History without Documents": The Vexed Archives of Decolonization in the Middle East. The American Historical Review 120: 920-34. [CrossRef]

Shetty, Sandhya, and Elizabeth Jane Bellamy. 2000. Postcolonialism's Archive Fever. Diacritics 30: 25-48. [CrossRef]

Stoler, Ann Laura. 1995. Race and the Education of Desire: Foucault's History of Sexuality and the Colonial Order of Things. Durham: Duke University Press. 
The Killing of George Floyd Sparks Controversy over African-Iraqi Rights. 2020. Al-Monitor. June 9. Available online: https: / / bit.ly/3vBbM7C (accessed on 28 May 2021).

Toledano, Ehud R. 1998. Slavery and Abolition in the Ottoman Middle East. Seattle: University of Washington Press.

Youssef, Saadi. 2003. Without an Alphabet, Without a Face: Selected Poems of Saadi Youssef. Translated by Khaled Mattawa. Saint Paul: Graywolf Press. 